\title{
石川県能登半島の歴史と景観の形成過程
}

\author{
柳井 清治 ${ }^{*}$ \\ 石川県立大学生物資源環境学部 $\bar{T}$ 921-8836 石川県野々市市末松 1 丁目 308 番地
}

\section{Deciphering landscape: history and development of landscape in the Noto Peninsula}

\section{Seiji Yanai}

Department of Environmental Sciences, Ishikawa Prefectural University, 1-308, Nonoichi, Ishikawa, 921-8836, Japan

Key Words: Noto Peninsula, Satoyama and Satoumi landscape, The middle ages, Rice terrace, Landslides キーワード : 能登半島, 里山・里海景観, 中世, 棚田, 地すべり

はじめに

2014 年 6 月 29 日に行われた第 24 回日本景観生態 学会金沢大会のエクスカーションは能登半島におい て行われた（図 1). 当日はあいにく雨で前半の千里 浜海岸・気多大社の見学は雨の中行われたが，午後 から雨も上がり, 柳田の里山景観, 白米千枚田では 美しい日本海と棚田を見学することができた。視察 地で観察した景観を題材として, 景観の成り立ちと それがいつどのようにしてできたのか，人々はそれ にどのように関与してきたのかについて読み解いて みたい。

\section{砂浜海岸「千里浜」の成り立ちと浸食}

\section{1. 車で走れる砂浜海岸}

金沢駅を出発するとバスは能登里山海道と呼ばれ る自動車専用道路に入り，美しい日本海と砂浜海岸 を見ながら北上し，30 分ほどで千里浜（ちりはま） 海岸に到達する。千里浜海岸は全国でも珍しい「車 で走れる砂浜海岸」として有名であり，例年多くの 観光客がバスや自家用車で訪れ，砂浜のドライブを 楽しんでいる(図2).

*連絡先 : yanai@ishikawa-pu.ac.jp

受付 : 2014 年 12 月 3 日/受理 : 2014 年 12 月 3 日
何故この海岸で車が走ることができるのであろう か? その秘密は海岸を構成する砂の粒径にあるとい われている. 普通の砂浜の砂は, 顕微鏡で見てみる と大きさがバラバラであるが，千里浜の砂はひとつ ひとつの粒が小さく，また大きさが揄っていて，角

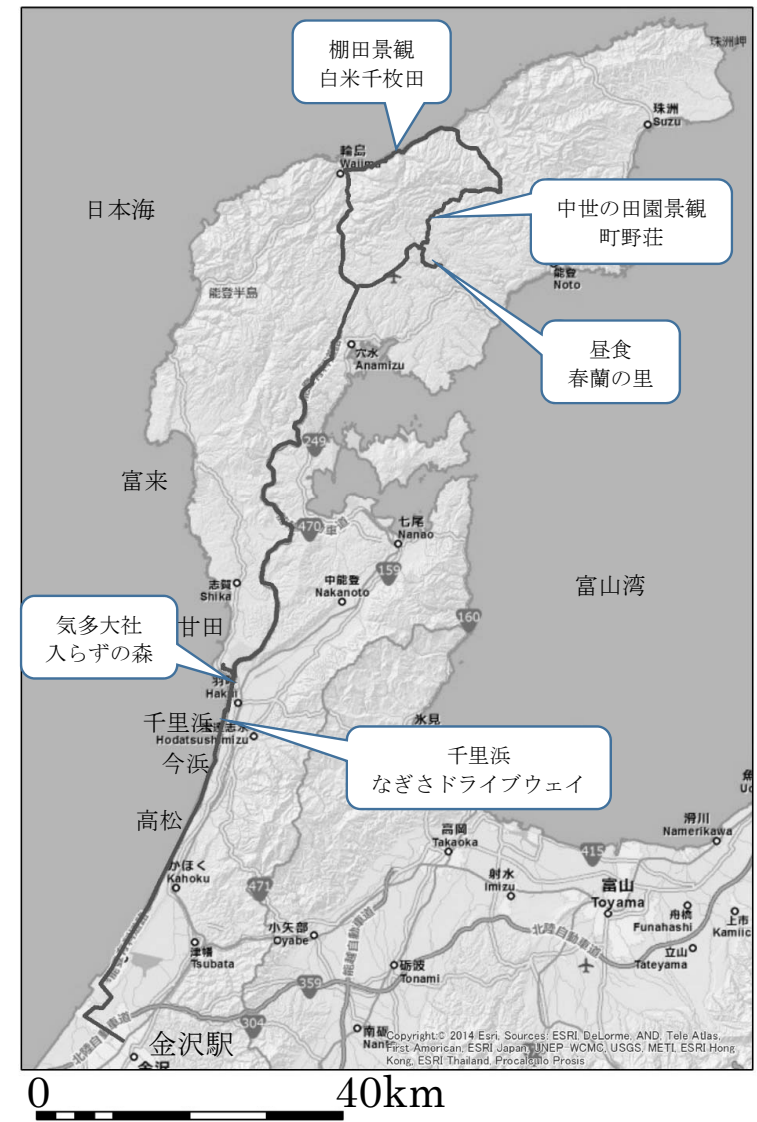

図 1. 景観生態学会金沢大会エクスカーションコース. 
ばった形をしているという特徵がある。なぜ千里浜 にこのように特別な砂が溜まっているかというと， ここから南方に位置する手取川や大海川，宝達川か ら海へ流れ出た砂が, 沖の方から海流や風で浜辺へ 押し戻され，その過程でより細かくなった砂が徐々 に千里浜近辺に堆積していったと考えられている. 実際に近隣の 5 地区(図 1 に示した)で砂を採集して, ふるいにかけて粒径を測ってみた（図 3)。その結果, なぎさドライブウェイ始点の今浜と終点の千里浜で は $125 〜 250 \mu \mathrm{m}$ の粒径が $90 \%$ を占め，非常に均一 な砂粒から構成されていることが分かった。このき め細やかな砂に適度な水分が混ざると砂浜は固く絞 まり，普通の道路のように車や自転車などで走行可 能になるのである.

\section{2. 砂浜にすむ絶滅危惧種}

生き物に乏しいとみられがちな千里浜付近の海岸 には実は貴重な生物種が確認されている。千里浜よ り北部に位置する柴垣，甘田海岸にはレッドデータ ブックにおいて絶滅危惧 I 類に指定されているイカ リモンハンミョウ（学名：Abroscelis anchoralis）が 分布しており（図 4), この場所は国の天然記念物に も指定されている．イカリモンハンミョウは局所的

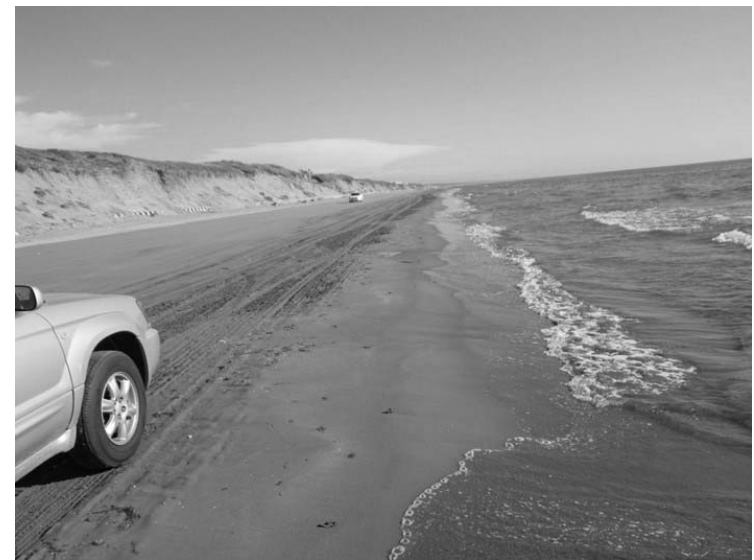

図 2. 車で走れる千里浜海岸.

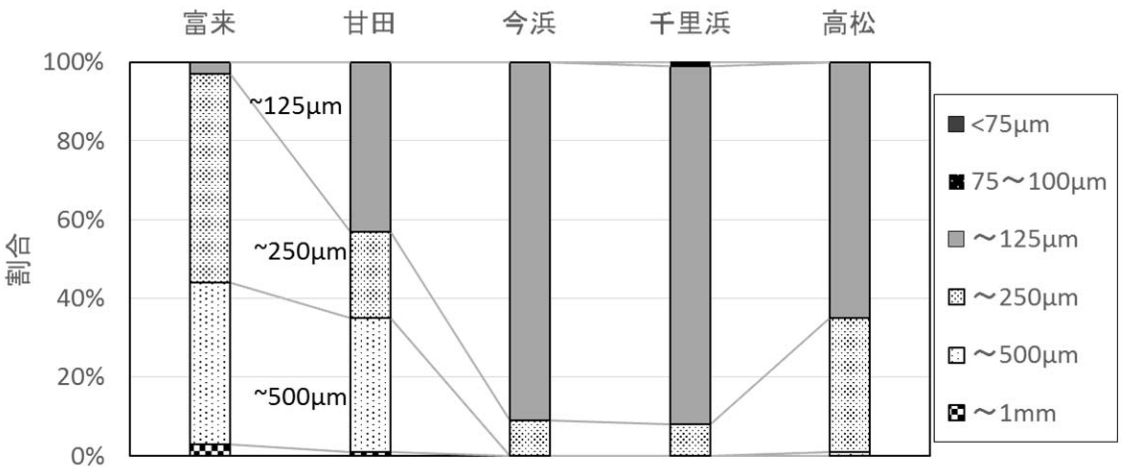

図 3. 千里浜周辺地域 5 地点の砂浜粒径組成割合. 

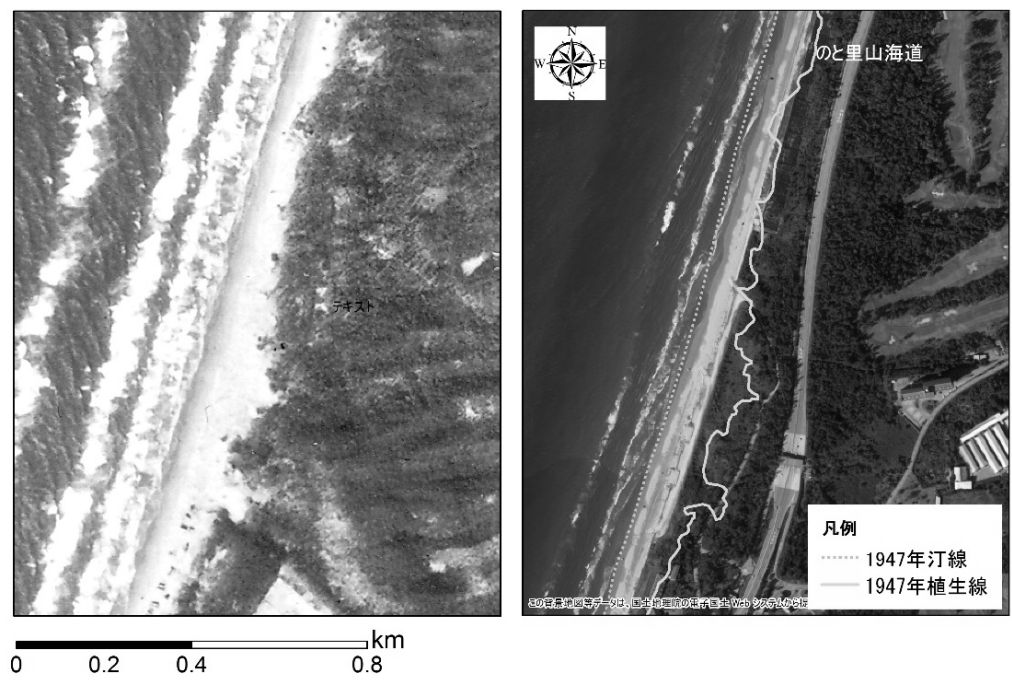

図 5. 千里浜南部における航空写真の比較による地形変化. (左 1947 年米軍航空写真, 右 2012 年電子国土 web 版航空写真) .

による海面上昇，石川県南部に位置する手取川に存 在する排砂機能の無いダムによる砂の供給量の低下 などが挙げられている.

石川県はこの事態を深刻に受け止め，保全対策と して 1984 年より年間平均約 $5000 \mathrm{~m}^{3}$ の陸上からの養 浜を行っている。 2005 年には，多面的に千里浜海岸 保全について検討するために「千里浜海岸保全対策 検討委員会」を設立し，大規模な養浜と人工リーフ 工法による保全対策を施工した。そして，2011 年か ら新たな試みとして，金沢港の浚渫土砂を海上投入 し漂砂によって千里浜に砂を供給するシステム等の 検討を行った。この他に，『千里浜なぎさふれあい教 室』等の住民参加型のイベントを毎年開催し, 地域 住民だけでなく，石川県全体に対して海岸保全への 意識の向上を試みている（石川県千里浜再生委員会 2011).

実際に 1947 年と 2012 年に撮影された空中写真を 見比べ，65年間の地形変化を比較した。確かに 1947 年当時白い砂浜は広がっていたが，2012 年にはその 面積が半分程度になっていることが分かった（図 5). しかし汀線そのものの位置は著しく変化してない. これはどのように考えたらよいのであろうか? 実は 植生ラインが著しく前進し，その分砂浜の幅が減少 したことがわかる。かつては海岸部では植生がそし く, 飛砂が激しいことから，砂防林が古くから造成 が行われてきた. 戦後, 飛砂防止のためニセアカシ アやクロマツなどの樹木が植栽され，現在も森林造 成が続けられている。こうした砂浜の固定化は移動 可能な砂量の減少を引き起こし，砂浜の安定化はさ らに植生の侵入を引き起こし, 砂帯幅の減少を引き
起したことが考えられる。砂浜後退の原因は様々で あるが，砂浜景観を保全するためには，長年にわたっ て続けられた植林の在り方も考え直すべき時期にあ るのかもしれない.

\section{「入らずの森」気多大社の原生林}

\section{1. 入らずの森の林相}

次に我々が訪れたのは，縁結びの神様と知られる， 羽咋（はくい）市にある気多（けた）大社である。 この神社の歴史は古く，気多大社由緒によれば奈良 時代大伴家持が参詣し歌を詠んだことが万葉集に記 されている，その社叢は「入らずの森」と呼ばれ， 加賀藩の保護を受け古くから人の出入りと樹木の伐 採が禁止された森で, 石川県内でも有数の原生状態 を保つ森として知られており, 昭和 47 年に国の天然 記念物に指定された。

森の入り口には自然木で作られた古びた鳥居が入 口を示しており，その間から森の様子を垣間見るこ とができる（図 6)。森林を構成する樹木はスダジイ， タブノキが中心であり，中層木としてヤブツバキ， ヤブニッケイ，シロダモ，林床にはヒメアオキ， ベ ニシダ，カラタチバナなどからなる，この地域で見 られる典型的な照葉樹林となっている．大径木の樹 幹には，常緑性の胞子植物であるマメジタびっしり と着生している．林床にはタブノキの枯損木がその まま放置されており，それが腐朽して土壌となり， 次世代の森の栄養源となる。しかし林内は楥蒼とし ており，次世代の後継樹はほとんど育ってはいない. 林内には小川が流れており，地形も起伏に富むが， 
その一部には墳墓があり, そうした人為的な石の配 置などから見て，古くは祭礼の場でもあったといわ れている。

この社叢が近年地元の新聞紙上を賑わせる出来事 が起こった。というのは，市の委託を受けた業者が 周辺の歩道整備を行った際, 誤って森の一部の樹木 を伐採してしまったというものである。伐採された 樹木は原生林ではなく, 林縁部のスダジイ, コナラ, ヤマザクラなどの中径木が中心であるが，森の活用 のために樹木を伐採するという皮肉な行為であり，

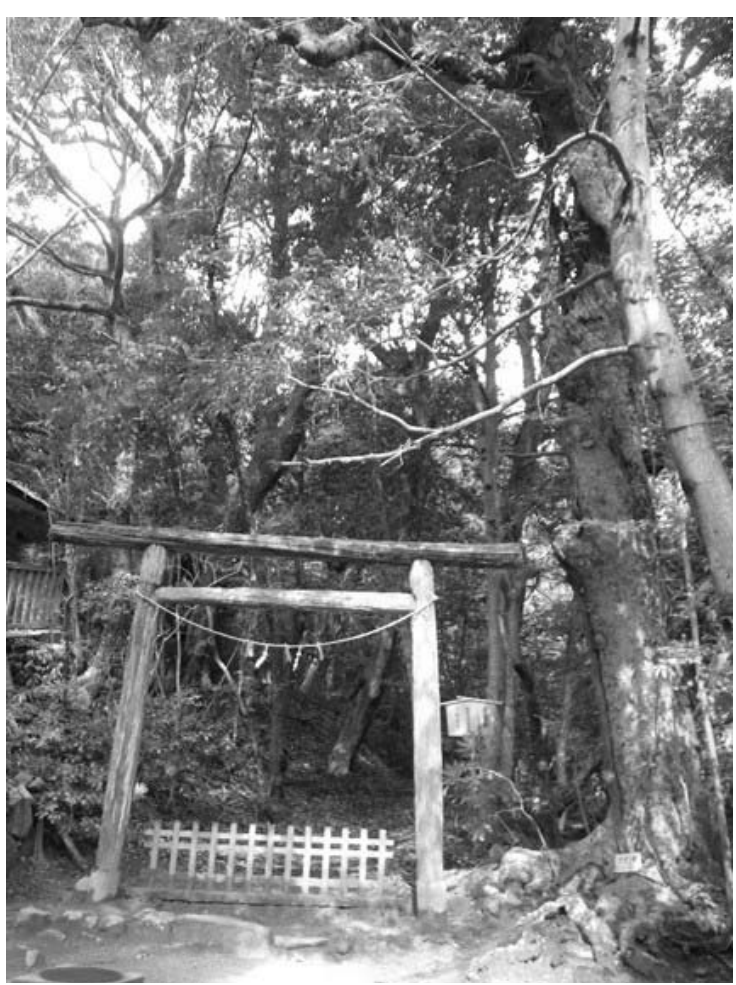

四 6. 入らずの森の入り口。これより中には一般人は立ち 入りが禁じられている.
森の価值が十分認識されていないことを世間が知る きっかけとなった。

\section{2. 入らずの森に入らずして森を知る}

林内には足を踏み入れることができないので，外か らは林内の様子を垣間見るだけであるが，最近撮影さ れたレーザープロファイラーのデータにより, 森林構 造を知ることができる，レーザープロファイラーとは 航空機に掲載されたレーザーの発射装置と受信装置を 組み合わせたもので，地上部の樹木や地面に跳ね返っ たレーザー光の位置を正確に把握することで，地物の 座標 (緯度, 経度と標高) を計測できるシステムである. ここでは 2006 年に撮影されたレーザーデータを北陸電 力より提供を受けたので, そのデータを解析し, 立体 図を作成した（図 7)。神社の周辺に大径木が集中し, その周辺には小径木が分布する。樹林の構造を見ると 大径木のブロックが南部に集中しており，北部には森 林は比較的薄く，また林内に隙間（ギャップ）も数多 く分布していることが分かる．中央部の断面をとって みると，段丘上に発達寸る樹木の上層木の樹高は $20 \mathrm{~m}$, 中層木が 5 〜 $10 \mathrm{~m}$ ，そして林床にも低木の存在を認め ることができた.

\section{3. 入らずの森の今後}

エクスカーションには全国から森林・植生の専門 家が多く参加しているので，入らずの森を見た感想 や今後の管理と保全の在り方について尋衫てみた。 その結果, 以下の 4 点に集約された. 1) 入らずの森 をこのまま立ち入り禁止の状態にすることは継続す るにしても, 学術調査を行い, 科学的データをとる

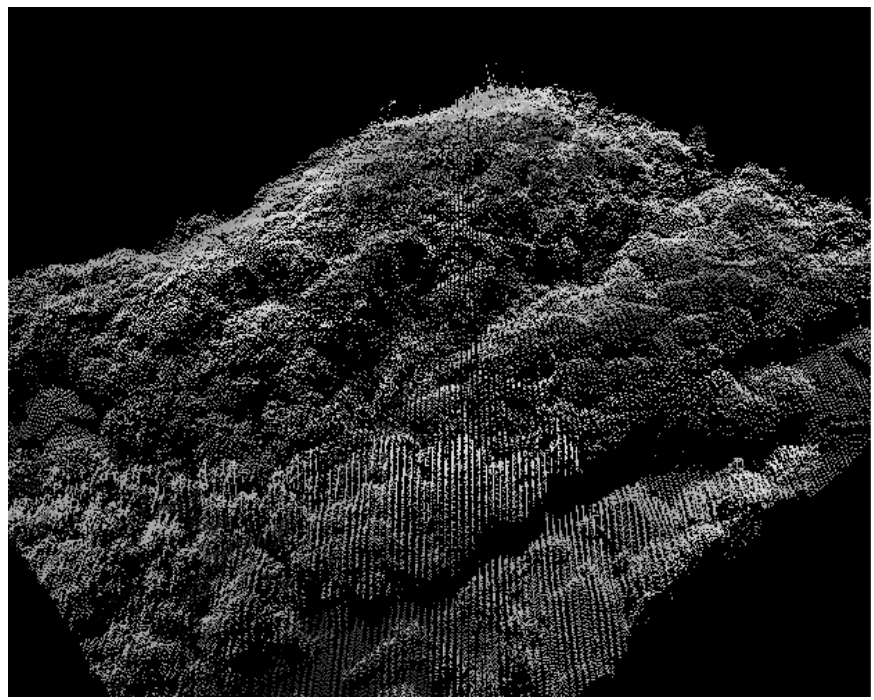

図 7. LIDARから作成した「入らずの森」周辺の景観図. 
ことは必要，2）入らずの森の意義を積極的に市民に アピールしてゆくことも重要，3）原生林は保護して ゆくには狭すぎるので，周辺林分を含めたバッファ ゾーン（緩衝帯）を作ることが必要，4）伐採箇所に 関しては手を付けずにそのまま見守る意見と苗を育 てて補植，あるいは防風垣を築設することなどの意 見に分かれた。今後必要に応じて，自生樹木を用い て苗木を育て，それをもって補植する等の手法が必 要となる。ささらに地域住民とのかかわりの中で管理 を考えてゆくべきであろう。

\section{中世が残る柳田地区の景観と文化}

奥能登地域には中世にまつわる地名，住居そして 伝統が色濃く残っている。例えば源義経と武蔵坊弁 慶一行が逃走の際立ち寄った神社や，栄華を誇った 平家一門の平時忠の流刑地などである．時忠の子孫 は輪島市を流れる町野川の下流に居を構えて, 時国 家を名乗り，豪農として名を残している，その住居 は現在重要文化財となり多くの観光客が訪れる観光 スポットになっている。また神事「あえのこと」は 奥能登一帯に伝わる田の神の伝統行事である。田の 神様を自宅に招き，豊作の感謝と願いをこめる，奥 能登のあえのことは，国の重要無形民俗文化財とユ ネスコの世界無形遺産に指定され，古式と厳格さを とどめたきわめて貴重な伝統行事とされている.

\section{1. 町野荘復元プロジェクト}

金沢学院大学東四柳研究室と能登町教育委員会は, 能登町柳田地区を中心として，中世に存在した荘園 の復元に精力的に取り組んでいる（図 8)。能登町柳 田地区（旧柳田村）は，中世（平安後期〜戦国）に おいて「町野荘」（まちのしょう）と呼ばれた荘園で あった，地区内には，当時から受け継がれている文 化財や伝承，景観が多く所在しているが，その実態 は不明瞭であり，住民の間にもほとんど知られてい ない。また，地域住民に語り継がれてきた伝承は， 社会環境の変化により失われつつある。このプロジェ クトでは，古文書調查や住民への聞き取り調査など 学術的面からアプローチするとともに，住民への情 報提供や観光資源等としての活用法を提案している (東四柳ほか 2012)。この結果, 中世において「町野荘」 は, 公田数（田地の面積） 200 町, 能登国では珠洲郡 若山荘（公田数 500 町）に次ぐ田積を誇る大規模な 荘園であったことが明らかになりつつある.

\section{2. 中世文書に見える地名比定}

町野荘の場合, 絵図類が全く残されていないため, 視覚的な面から中世と現在の姿を比べることができ ない。しかし, 当時の姿を探ることができるキーワー ドとして「地名」が挙げられる。東四柳ゼミの調査 によれば，柳田地区平等寺に所蔵されている天正 15 年（1587）の田帳には，この寺が所有していた水田 の通称名が列記されている。これを現在の地図上に あてはめ，住民への聞き取りから田帳に記載されて いる約 50 力所の地名のうち, およそ 20 力所の場所 を特定することができた. 当時と変わらず水田が機 能していると考えれば, 町野荘時代の農村景観がこ の土地に残されていると推測される.

\section{3. 灌涀用水の分布調査}

景観復元のもう一つの指標は水田の灌激施設であ る、稲を育てるにはため池や灌溉水路が不可欠であり， これらは古くから築造され，現在も使われているもの が多い，そうした用水名は古文書や聞き取りにも表れ， それが景観復元の手がかりになるというものである. 現地で案内して頂いた用水は凝灰岩を削ったもので, 山裾を這うように作られている（図 9)。こうした用水 は古くからこの地域の水田を潤し，人々は稲を耕作す

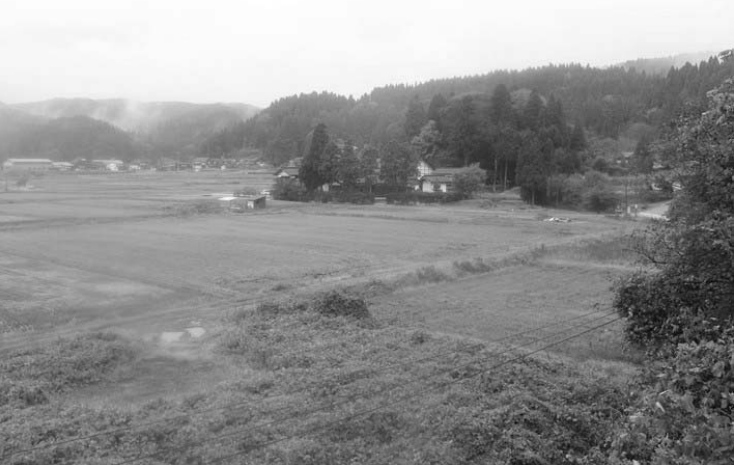

図 8. 能登町柳田地区の田園景観. 中世に存在した荘園の 復元プロジェクトが進められている。

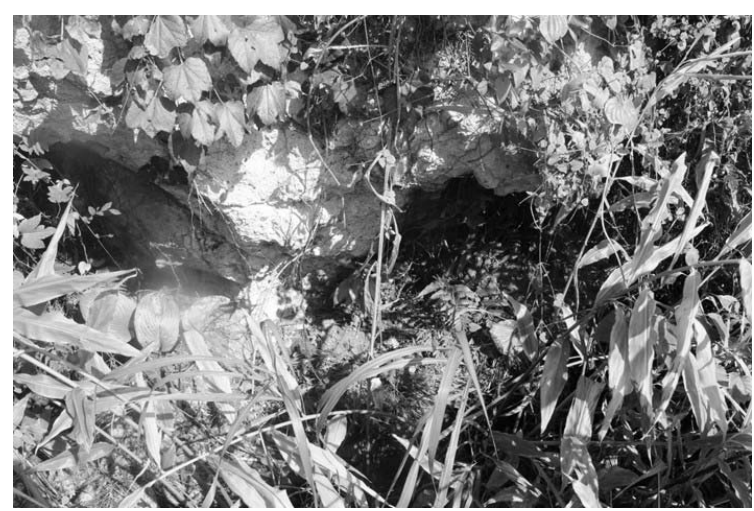

図 9. 凝灰岩をくり抜いた古い灌溉水路. 柳田地区の随所 にこうした用水が残されている. 
ることが可能となった，その営みは数百年の時間を経

て，脈々と受け継がれているのである.

\section{地すべりが千枚田を作り上げた}

最後の見学地は輪島市の外浦地区にある, 白米（し ろよね）千枚田である（図 10）。能登半島の西側は 北西からの季節風が直接吹き付け, 急峻な断崖が連 続し外浦と呼ばれているに対し，富山湾側は能登の 春梁山地で季節風が遮られ，穏やかな内湾となり内 浦と呼ばれている. 外浦は, $300 \mathrm{~m}$ 前後の山々が尾 根を連ね，急傾斜のまま日本海に落ち込む．水田適 地を持たない外浦の住民は，このような海岸沿いの 急峻な傾斜面を切り開き，水田とせざるを得なかっ た。輪島市から東の名舟にかけての海岸地帯は, 連 続した地すべり地帯が形成されている（図 11）。こ のような地すべり地帯は, 比較的水が豊富で, 土䁃 的にも稲作に適していることから，急斜面に沿って 階段状に耕作され, 幾重にも連なる畦が幾何学模様 を描く, 独特の棚田景観が作り出された（小出

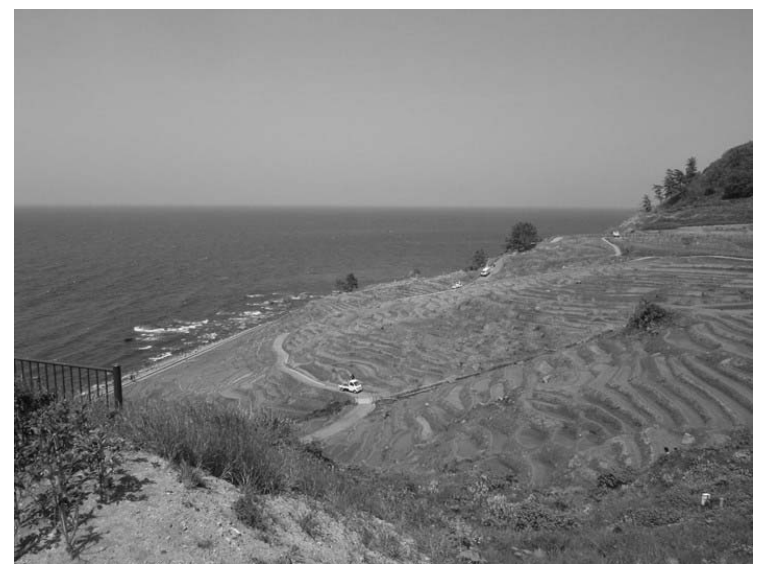

図 10. 白米千枚田の全景. 日本海が背景にみられる棚田と して有名. 小さい水田を数えると千枚近くある.
1973)，棚田が海岸近くにまで及ぶ，輪島市白米町の 「白米の千枚田」は，その代表である。

\section{1. 千枚田周辺の地すべり地形}

白米では, 標高 $4 \sim 60 \mathrm{~m}$, 傾斜 $1 / 4$ の斜面に, 水 田がひらかれ, 集落背後の標高 $80 \sim 110 \mathrm{~m}$ の斜面に は, 畑が拓かれている. 集落は, 畑と棚田の間の湧 水がある標高 $70 \mathrm{~m}$ 付近の斜面に立地している. 地 すべり地形は急峻な崖（滑落崖）と比較的なだらか な移動体から成り立ち, 千枚田はまさにその移動体 上に作られたものである. さらに千枚田の南方, 山 地にかけていくつもの地す心゙り地形が重なり合うよ うに分布している。これらの移動体も以前はほとん ど水田や畑として利用されており, 急峻な滑落崖と その背後の山林は, 主にコナラ林や落葉低木林が広 がり，スギの植林地もみられた。1975 年に撮影され た航空写真（図 12 上）によれば, 白米千枚田の上部 から稜線にかけて多くの耕作地が存在しており, そ の面積は千枚田のゆうに 3 倍を超える面積であった。 しかし 2010 年の航空写真では白米千枚田より上部の 耕作地の多くは, 放棄され樹林化が進んでいること がわかる（図12下）。

白米の棚田はすべて土坡（どは）と呼ばれる泥で 作られている. 田村（2003）によれば，土は粘り気 のある珪藻土で, 風化して粘土のようになっている. この土はロームと呼ばれ時として滑動し, 複雑なう ろこ状の棚田地形が作られたのである. また海岸付 近標は岩礁海岸となっているが, かつては砂浜が広 がり, 塩田となり製塩が行われていたという。また 明治時代の絵図から計測したところ，かつての白米 の耕地は 7995 枚あったと述べられている.

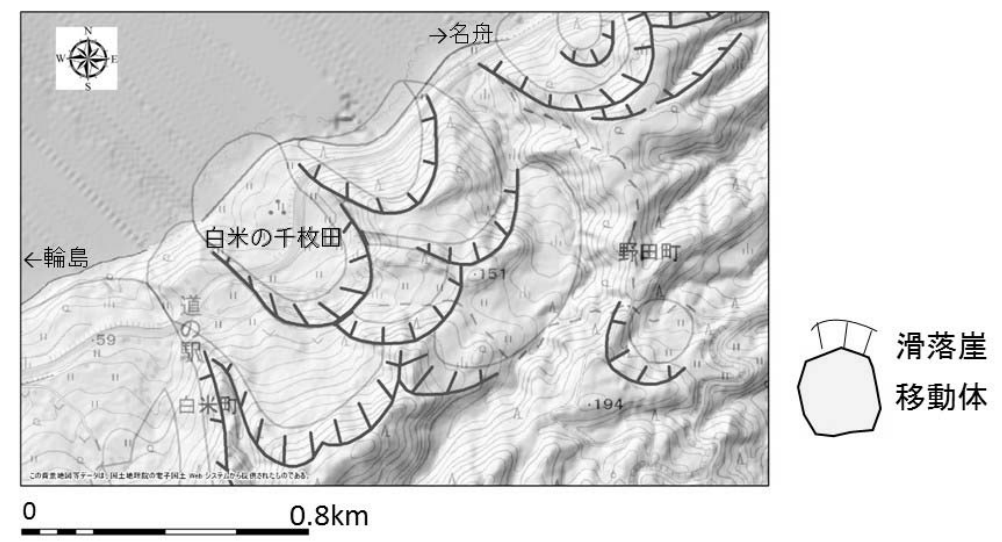

図 11. 白米千枚田周辺の地すべり地形. 電子国土地形図（2014）と防災科学技術センター （2013）の地すべり分布図を重㸚合わせた。 

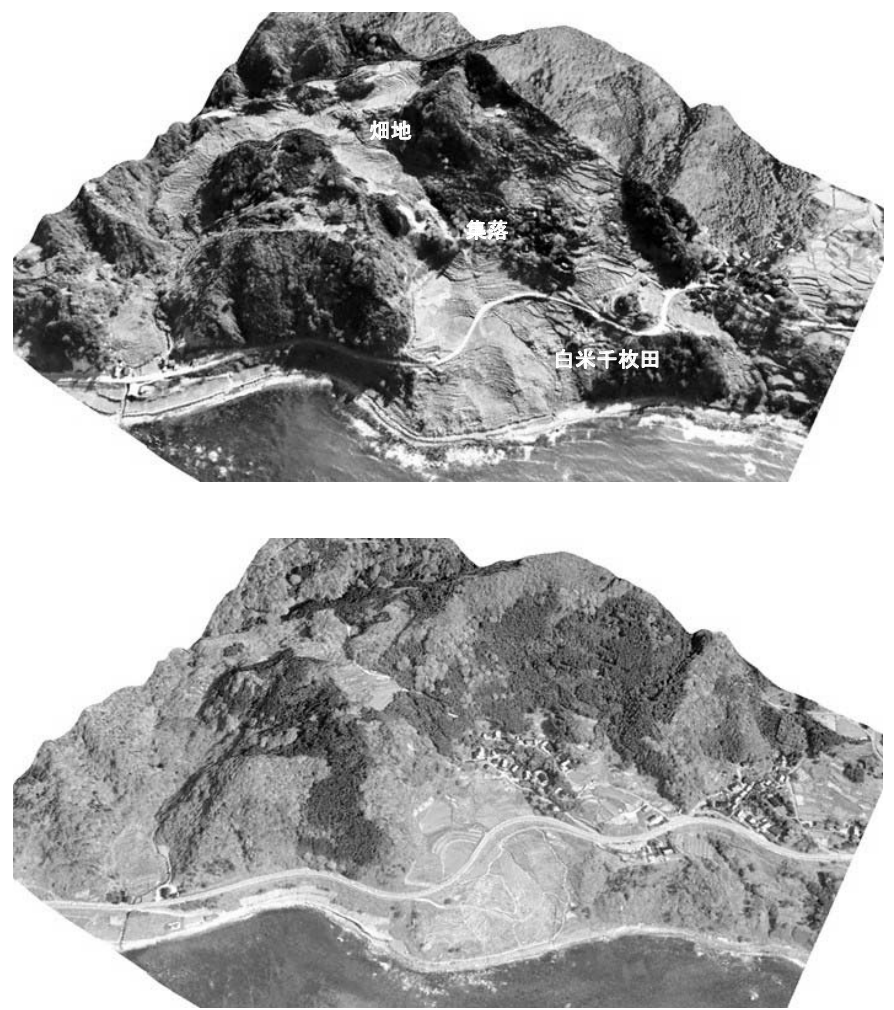

図 12. 白米千枚田の景観の変遷. 電子国土 web 版（2014）1975 年航空写真（上）と 2010 年航空写真（下）を比較したもの.

\section{2. 地すべり防止対策}

白米地区においても 1970 年から地す心゙り防止法に 基づき石川県が地すべり防止対策工事を施工されて いる。ボーリング調查から，すべり面は地表から 10 $\mathrm{m}$ 程度の地中に存在寸ることが述べられている（農 林水産省 2009)，一般的に地す心゙り防止工事はす心゙ り面に杭を打ち移動を食い止める工法や，滑りを助 長する地下水を井戸を掘って集め, 排水する工法な どがとられている、ポケットパークから見ると柵に よって守られた集水井戸の蓋があるのを観光に訪れ た人はほとんど気づかない（図 13). 集水井は内径 $2 \sim 4 \mathrm{~m}$ の円形の井筒であり, 井筒からの集水ボー リングはすべり面に直接関与する地下水帯の地下水 を効率よく集水できるように配置されている.

また地すべり地帯の中央を横切る国道 249 号線に も特別な工夫が施されている. それは地すべり地帯 であることを考慮し，軽量盛土材を使用した工法 （EPS 工法）を用いられている。これは，大型の発泡 スチロールブロックを盛土材料として積み重ねてい くもので, 軟弱地盤上の盛土などの荷重軽減および 土圧軽減をはかる必要のあるところに適用され，そ の施工例としては当時日本初といわれていた。しか し地すべりが作り出した棚田を今後維持するために は, 移動を完全に止めるのではなく, ある程度許容

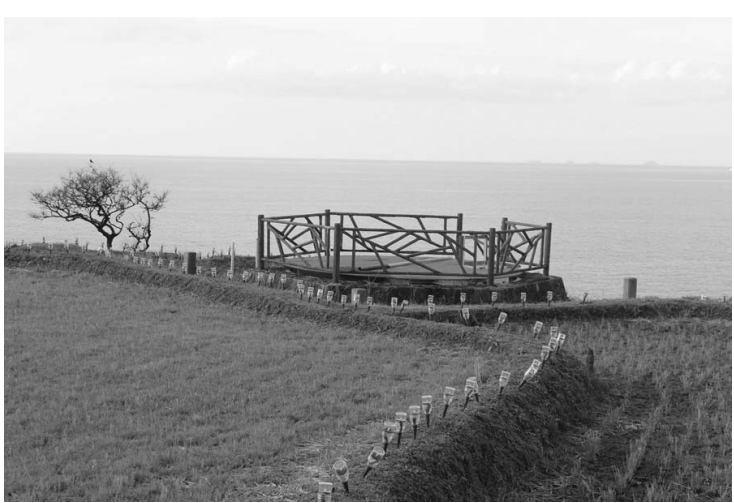

図 13. 白米千枚田内に作られた地すべり対策のための集水 井戸.

しながら長い付き合いをしてゆくことが求められて いる。

\section{おわりに}

エクスカーションで訪れた場所を題材に，景観の 成り立ちと人のかかわりを述べてみた。訪問地の景 観を思い浮かべてその中に込められた歴史を少しで も理解いただければ幸甚である。最後にエクスカー ションに協力いただいた多くの方々に深謝する. 


\section{引用文献}

（独）防災科学技術研究所. 2013. 地すべり地形 GIS データ：地すベり地形分布図データベース. http:// lsweb1.ess.bosai.go.jp/ 2014 年 11 月 30 日参照.

石川県千里浜再生プロジェクト委員会. 2011. http:// www.pref.ishikawa.lg.jp/kasen/chirihama-saisei/ 2014 年 11 月 30 日参照.

東四柳史明ほか. 2012. 能登国町野荘の調查と利活 用. 平成 24 年度地域課題ゼミナール支援事業成果 報告集, 大学コンソーシアム石川 : 37-40.

小出博. 1973. 日本の国土下. 556pp. 東京大学出版 会, 東京.

国土地理院. 2014. 電子国土 Web システム技術情報. http://portal.cyberjapan.jp/ 2014 年 11 月 30 日参照. 農林水産省. 2009. 千枚田と地すべり : 石川県輪島市. http://www.maff.go.jp/j/nousin/noukan/tisitu/t senmaida/ 2014 年 11 月 30 日参照.

田村善次郎. 2003. 棚田の謎一千枚田はどうしてで きたのか. $175 \mathrm{pp}$. 農文協, 東京. 